\title{
Collaborative work and reflective practice to improve teacher's performance
}

\section{Trabajo colaborativo y práctica reflexiva para la mejora del desempeño docente}

PEÑA-GALEANA, Ricardo $\dagger^{*}$, PEÑA-GALEANA, Norma Ivone and LÓPEZ-SILVA, Saúl

Universidad Autónoma de Guerrero, México.

ID $1^{\text {st }}$ Author: Ricardo, Peña-Galeana / ORC ID: 0000-0002-5048-7799

ID $1^{\text {st }}$ Coauthor: Norma Ivone, Peña-Galeana / ORC ID: 0000-0003-3827-7817

ID $2^{\text {nd }}$ Coauthor: Saúl, López-Silva / ORC ID: 0000-0002-1027-8028

DOI: $10.35429 /$ EJS.2020.13.7.7.16

Received July 21, 2020; Accepted December 10, 2020

\begin{abstract}
In search of improving the teaching-learning process in higher education, a Teacher's Performance Assessment Model was designed by answering six questions (What for? Who? When? How? Expected problems? Expected outcome?). This model emphasizes collaborative work and reflective practice among teachers, students and managers, and applies performance indexes that are generated using information provided by the management staff and students' opinion collected by a web system built for it. Finally, management staff and teachers use these indexes to design general and individual strategies to improve teachers' performance. The proposed Assessment Model is described here, including the assessment process, its advantages and problems, and results obtained during its application in a University in Sothern Mexico.
\end{abstract}

Teacher's performance assessment, Reflective practice, Collaborative work

\begin{abstract}
Resumen
En busca de mejorar el proceso de enseñanzaaprendizaje en la educación superior, se diseñó un Modelo de Evaluación del Desempeño Docente respondiendo seis preguntas (¿Para qué? ¿Para quién? ¿Cuándo? ¿Cómo? ¿Problemas esperados? ¿Resultado esperado?). Este modelo enfatiza el trabajo colaborativo y la práctica reflexiva entre maestros, estudiantes y directivos, y aplica índices de desempeño que se generan utilizando la información provista por el personal administrativo y la opinión de los estudiantes recopilada mediante un sistema web creado para ello. Finalmente, el personal administrativo y los maestros usan estos índices para diseñar estrategias generales e individuales para mejorar el desempeño de los docentes. El modelo de evaluación propuesto se describe aquí, incluido el proceso de evaluación, sus ventajas y problemas, y los resultados obtenidos durante su aplicación en una universidad en el sur de México.
\end{abstract}

Evaluación del desempeño docente, Práctica reflexiva, Trabajo colaborativo

Citation: PEÑA-GALEANA, Ricardo, PEÑA-GALEANA, Norma Ivone and LÓPEZ-SILVA, Saúl. Collaborative work and reflective practice to improve teacher's performance. ECORFAN Journal - Spain. 2020. 7-13: 7-16.

\footnotetext{
* Correspondence to Author (E-mail: rpgaleana@msn.com)

$\dagger$ Researcher contributing first author.
} 


\section{Introduction}

Conceptualizing the teaching-learning process as a living system, leads to the conclusions that: a) characteristics and behaviour of the specific elements in the system (and their interactions) affects its outcomes; and b) that its elements and interactions will present variations over time (Bertalanffy, 1969; Van Gigch, 1990; Wilson, 1995).

The internal structure of this system thus conceptualized includes: a) Physical and organizational infrastructure available for the teaching-learning process in each school, b) Actors involved (students, teachers and managers), and c) Interaction between each of these elements. Having information regarding these three factors will facilitate the design of strategies that ensure the continuous improvement of the process and the academic quality of its students.

In this regard, a University in Southern Mexico developed different methods and tools for collecting and processing information, used this information to generate indexes (such as students per teacher ratios, students per group ratios, average grade per cohort, dropout percentages, and so on) and used these indexes to design general improvement strategies, applied at institutional level.

Additionally, this University created a Program (for practical purposes, hereinafter referred as "Monitoring Program" or MP) through which professors monitor and evaluate the individual performance of several students assigned to them, and define personalized strategies to improve each student's performance.

However, individual performance of each professor in the classroom was not assessed, and student's opinion regarding to said performance was unknown, so that personalized strategies to improve teachers' performance were not generated or applied.

Based on the foregoing, a group of professors at this University decided to develop a Teacher's Performance Assessment Model, in order to facilitate the design and application of flexible strategies, both general and individualized, to improve teachers' performance and create a positive impact in the teaching-learning process at the University

\section{Methods}

Using Peter Checkland's Soft Systems approach (1999), teacher's performance was defined as a problematic situation where participation of actors in problems definition, tools construction and solutions design and application are a necessity; and where any improvement proposal must have a flexible character, adaptable to specific persons involved, academic periods and organizations.

Under the late idea, this project emphasized the teacher-student relationship and included the participation of the three actors involved in the teaching-learning process (teachers, students and managers). A mixture of several approaches was also applied: the analysis of teacher behavior in the classroom (Sondang, Perlindungan \& Bonik, 2018; Sztejnberg, Brok \& Jurek, 2004), the application of reflective practice (Loughran, 2002; Mathew, 2017; Sunday, 2013), and collaborative work as a way to carry out actions (Barker, 2017, Thompson, 2016).

With this base, the project was developed in four stages, as follow.

\section{Framework Definition}

Several meetings were held in order to sensitize participants and create a framework to organize activities.

It was decided that administrators and a group of the same teachers will be in charge of conducting the activities, and it was agreed that all participants would collaborate in defining variables and tools to assess teacher performance.

Rather than categorizing a teacher based on a numerical indicator and use this information to hire, fire or grant a bonus, the aim was placed in the collective effort to develop and use a performance index for improving teacher's skills and thus for improving the teaching-learning process (Benton \& Young, 2018; Valdés, 2009).

The main concern of those involved was related to the level of confidentiality of the resulting information. In this regard, it was agreed that institutional averages for each variable evaluated would be treated as public information. Conversely, individual results could only be seen by administrators and specific teachers. It was also agreed that all students would be able to express their opinion regarding their teachers' performance, but this would be done anonymously. 


\section{Modelling and Tool Design}

Teachers and managers worked together to define which variables would be taken in account related to teachers performance assessment.

After a literature review, factors influencing teachers' performance assessment, tools used to generate and process information, and problems faced when applying a teacher's performance assessment process, were identified and classified (Campbell, 2014; Casanova, 2017; Del Rincón \& Del Rincón, 2000; López, García, Batte \& Cobas, 2015; Valdés, 2004).

This information was used to define relevant variables for the project, and to draw a conceptual map answering the following questions (Cárdenas, 2014; OCED, 2011):

- What for? (Aim).

- Who? (Subject providing information and/or assessing teachers' performance).

- When? (Time frame).

- How? (Methods and tools)

- $\quad$ Expected problems? (What problems may appear).

- Expected outcome? (What products are expected).

As participation in the Monitoring Program (MP) was considered important when assessing a teacher's performance, it was decided that number of tutored students and delivering of work plans and reports for the Monitoring Program would be held in account along with work attendance and academic meetings attendance.

Different questionnaires were analyzed to identify questions that allowed to know students' opinion regarding their teachers' performance (Barrado, Gallego \& Valero, 1999; Escalera, Reíllo Torrado \& Peña, 2012; Gómez, 2008; Univ Veracruzana, 2004; Univ Iberoamericana, 2010; SEP, 2011).

Using this information, a questionnaire was designed including twenty-one questions with multiple-choice answers, and one open answered question so students could give their opinion freely. follows:
- Nine questions regarding teacher's attitude, including: Attendance and punctuality, delivery of course plans and grades, knowledge of course topics, interest shown towards students, and promotion of trust and respect.

- Nine questions regarding teaching techniques and methods, including: teaching without losing the point of view; content consistent with the general theme of the learning unit; classes made interesting and with clear topics; encouraging of reasoning, self-study, and the ability to pose and solve problems; content expanded when necessary; and feedback delivery.

- $\quad$ Three questions regarding the tools used to reinforce and evaluate learning, including level of difficulty of examples, tasks, exercises and exams, and its contribution to learning.

A value between one and four was assigned to each answering option (except for one question, which had a maximum value of three) and, under the criterion "more is better", it was used to calculate the average value as the main performance indicator.

The group of teachers in charge of the process were assigned the task of design and create a Web Software to collect and process such data. This tool complied with the following requirements:

- To be available online for managers, professors and students of the same school, with access through a personal computer (PC) or a mobile device (laptop, or smart phone).

- To contain an editable questionnaire with open and closed answers.

- To calculate the average value corresponding to each question, individually for each course assessed and globally for all courses of the same school and period.

- $\quad$ To present average values on screen, and to allow the downloading of this information.

- Students would be the only ones who could answer the questionnaire. None of the actors would have access to the questionnaire once it was resolved. 
- A teacher could see and download average values corresponding to his/her assessed courses (individual values), as well as school's average values (global values). A teacher could not see or download average values corresponding to another teacher.

- Management staff could see and download individual and global average values.

- Management staff would be in charge of editing the questionnaire, creating courses (with specific learning units, teachers, and students), and opening and closing the Web System access.

Royce's Cascade Model (1970) was used as software development model, because it was considered to provide the ideal framework for this system. Krasner and Pope's ViewController Model (1988) was used to define the system's architecture. Free, standardized, and open source coding tools were used as well, including: PHP, HTML5, CSS3, Bootstrap, JavaScript, JQuery, AJAX, MySQL, NOTEPAD ++.

Once the Beta version of the Web System was built, a pilot test was carried out on 66 students, organized in two courses taught by two different teachers. After the test, participating professors and students were asked about questions suitability and system functionality, and improvements were made to both the questionnaire and the Web System.

\section{Collecting and Processing Data}

The Web System was used in September 2019 to assess teachers' performance during the February-July 2019 semester.

Afterwards, average values of each question were calculated for all professors as a whole, in order to know the teaching performance assessment for the School. These values (named global average) were classified by deciles, and were analyzed in order to identify general (global) strengths and weaknesses.

A table and a summary graph were constructed including, for each question: global average, expected value (defined as the ideal value, which reflects the better performance) maximum and minimum global values. This information was sent to both professors and Faculty managers by e-mail.
Average values associated to each course taught by each professor (individual average), were compared with the global average and with the expected value. In addition, minimum and maximum values per question and per teacher were calculated. With this data, individual performance graphs were constructed and sent to each professor by email.

Compliance percentages related to classes' attendance and periodic academic meetings attendance were calculated for both items and later classified by quartiles.

Number of tutored students was classified by quartiles and compliance with delivery of work plans and reports was classified as: I) Does not participates, II) Participates and does not deliver work's plan and reports, III) Participates and only delivers work's plan, and IV) Participates and delivers work plans and reports.

I $\mathrm{n}$ all cases, based on the opinion of professors and managers, a value ranging from zero to one (under the criterion of more is better) was assigned to each quartile. A greater weight (0.6) was assigned to students' opinion, rather than to managers' official information (0.4), because students were considered to have a more relevant role in the teaching-learning process.

This information was used to create a teacher's performance global indicator as follows:

$\sum_{1}^{n}(c * p)$

Where:

$\mathrm{n}=$ number of factors analyzed

$\mathrm{c}=$ quartile in which the factor is located

$\mathrm{p}=$ weight assigned to the factor

\section{Improvement Strategies Design}

Resulting information was sent to teachers and managers in order to provide a basis for critical reflection and individual and collective improvement strategies design, but always maintaining individual confidentiality in order to provide information for reflection without fearing that the information will be used against them and without creating a negative competitive environment among teachers (Schaak, L. \& Walker, J., 2004) 
Once the above was completed, a series of meetings were held where managers and teachers worked together on the identification of collective strengths and weaknesses, as well as on the definition of general strategies for improving teacher performance.

Likewise, individualized teachermanagerial meetings were held, in order to reflect on individual strengths and weaknesses, and define strategies to improve teacher performance in a specific way.

\section{Results}

Teacher Performance Assessment was defined as a collaborative process of obtaining and analyzing data concerning the deployment of an specific teacher's skills and abilities (including pedagogical, emotional and labor responsibility aspects), with the objective of providing information to help improve his/her teaching performance.

A conceptual map was constructed (Figure 1) and was used to answer the six defined questions related to teachers' performance assessment, as follows:

- What for? To improve teacher's performance.

- Who? Students, managers and the same teacher.

- When? Each semester, after the courses' end.

- How? Collecting students opinion through a questionnaire, using information provided by managers, building custom indexes, and applying reflective practice.

- Expected problems? Attitude problems (actors' hostility or indifference).

- Expected outcome? Performance indicators, strengths and weaknesses identification, and individual and global improvement strategies.

Throughout September 2019, an assessment of 13 teachers' performance was made (corresponding to 47 different courses taught in the February-July 2019 semester), and the following results were obtained:
- 196 enrolled students had access to the web system, but only 151 of them $(77 \%)$ participated by answering the questionnaire. When investigating the cause, it was found that 45 students had graduated or dropped out of their studies.

- 621 of 739 expected questionnaires were collected, which led to an $84 \%$ average response in each course.

- 10 of 13 professors $(77 \%)$ used the Web System in October 2019, to download their assessments results. When investigating the cause, it was found that three professors considered that downloading this data was unnecessary, because later they would receive by e-mail a graphic showing their average results.

To solve the problem of the low percentage of students' response, it was determined that the assessments should take place on the last day of the semester. In addition, as the information sent to professors was the same as the one available in the system, it was decided to take no action regarding the professors' low use of the system.

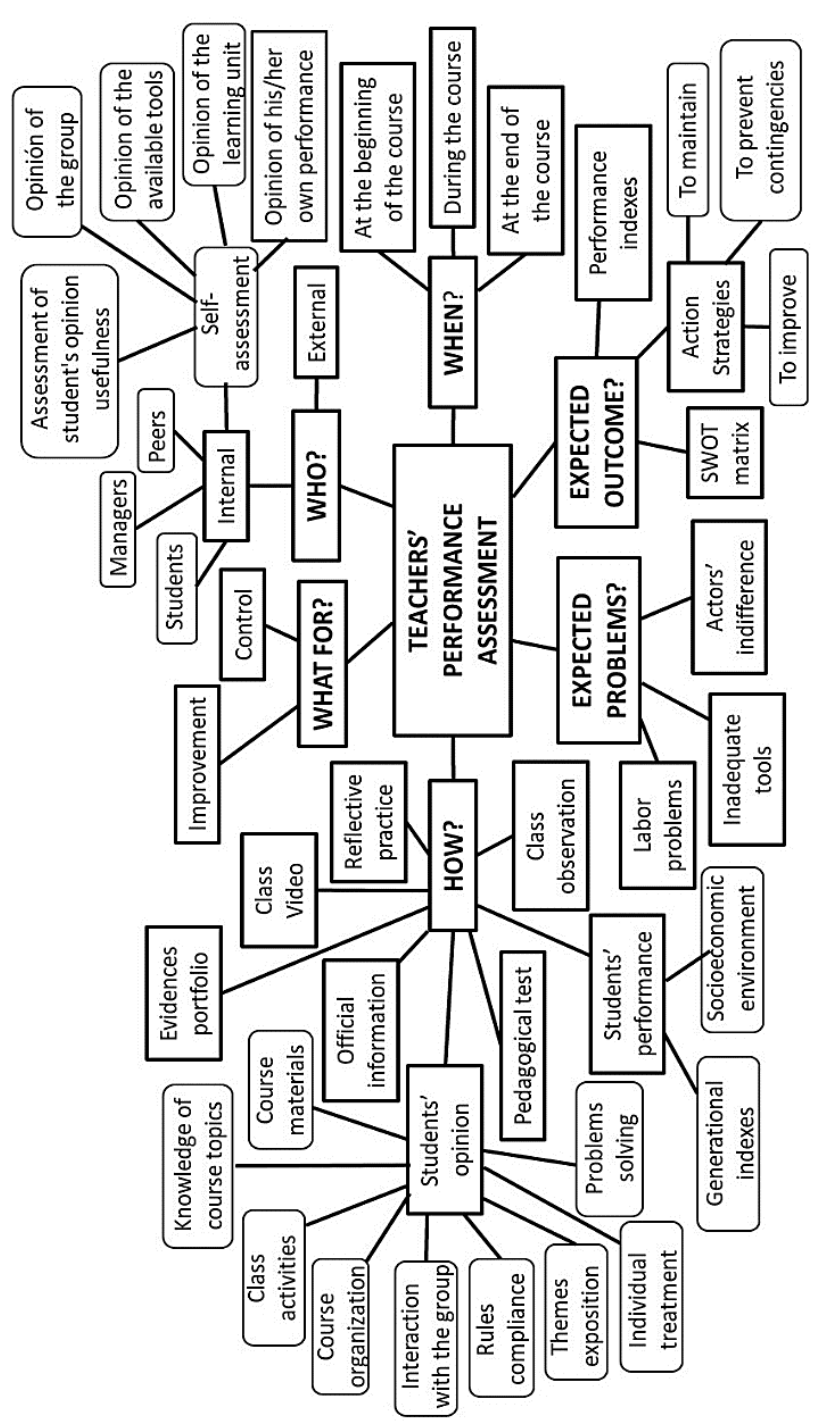

Figure 1 Variables related to teachers' performance assessment

Source: Authors

PEÑA-GALEANA, Ricardo, PEÑA-GALEANA, Norma Ivone and LÓPEZ-SILVA, Saúl. Collaborative work and reflective practice to improve teacher's performance. ECORFAN Journal - Spain. 2020 
For all professors, the average value was calculated considering all questions and all courses taught, and a summary graph was constructed including, for each question: global average, expected value (defined as the ideal value, which reflects the better performance) maximum and minimum global values.

About it, 18 of 21 questions (86\%) obtained an average value that places them in the top two deciles, which was interpreted as a favourable students' assessment of teachers' performance.

Questions "The teacher usually arrives in the classroom at the appointed time" and "The teacher finishes his class at the appointed time" were, on average, the best assessed. The foregoing was interpreted as positive evidence of professor time compliance in the classroom.

Question "The teacher expands theme contents when required" had the greatest deviation from the expected value, and question "The topics reviewed in class corresponded entirely to the subject", the minimum. The conclusion was that the main problem perceived by students is that professors adhere to course themes and do not always broaden the topics when needed.

Question "The teacher always grades and returns exams, assignments and projects" obtained the second lowest average value within the overall assessment. This was interpreted as the existence of a possible lack of feedback in relation to the student's academic performance.

For each professor, the average value per question was calculated considering all courses taught. Based on this information, an individual graph was made for each professor.

- $\quad$ Four professors were placed in the upper quartile; three of them had the highest values in 18 of 21 questions (85.7\%).

- One professor was placed in the lower quartile and obtained the lowest values in 16 of 21 questions $(76.2 \%)$.

These results were considered important, since observing these teachers' performance more closely will help to understand why students consider them to have the best or worst performance, and thus, to later decide which behavior should be copied or avoided.
Related to class attendance and participation in internal academic meetings, only one professor achieved $100 \%$ of class attendance during the semester under study. Overall, 38.5\% of professors registered the highest attendance percentages. These professors were placed in the upper quartile, while $15.4 \%$ of professors, were placed in the lowest quartile. These results validate students' opinion in question "The teacher missed class during the semester".

In order to identify and solve academic problems, seven meetings were held during the semester. Five professors $(38.5 \%)$, attended all meetings and were placed in the upper quartile. One professor was placed in the lowest quartile and another one did not attend any meetings, so it was assessed with a cero value.

Question one results ("The interest of the teacher for students' learning") and the above, helped to outline a trend in teachers' behavior, and was interpreted as a possible attitude problem for two professors that should be cause for reflection and discussion.

Ten out of 13 teachers $(76.9 \%)$ participated in the Monitoring Program (MP) by tutoring students and delivering work plans and reports in a timely manner. This percentage of participation was considered as a positive result, since teachers who did not participate were not full-time professors, therefore, were not contractually obliged to do so.

An unbalanced distribution in the number of tutored students per teacher was observed. Two professors (among the best assessed by students' opinion) accumulated the largest number of tutored students (28.1\%), while professors while another two professors (among the worst) accumulated the lowest amount (14.8\%).

A positive relationship between number of tutored students and students' assessment could be inferred from these results; however, one of the best assessed professors, by students' opinion, had fewer tutored students than one of the worst professor, which contradicts the above. Based on the late, two conclusions were made:

- If we assume that the emotional connection developed between students and professors working together in MP is a factor that affects students' opinion, based on the late it can be inferred that this emotional connection was not always achieved, and was not a decisive factor for students' opinion. 
- $\quad$ As each professor decides the number of tutored students, then it may be inferred that professors with more tutored students are more committed than teachers with fewer tutored students.

Finally, a global performance index was calculated based on the previous results. Values ranged from 0.35 to 1.00 were obtained, with a mean value of 0.775 . This information was delivered to Faculty managers and was shared with all professors in a personalized way.

Two professors obtained the maximum performance index value (1.0), and another two obtained a performance index value above 0.97 . Based on these results, their collaboration was requested to work along the management staff in improvement proposal design, for the entire school. For professors who obtained the lowest assessment, it was determined that, in addition to participating in general improvement activities, they had to choose between working along with Managers and/or another professor to design individualized improvement activities.

\section{Discussion}

A controversial aspect of the proposed model is students' participation in teachers' performance assessment. Authors such as Hornstein (2017) and Bunge (2018) argue that students are not able to assess a teacher, also that this action generates a negative relationship between teachers and students, it negatively affects students, and it creates dissatisfaction among teachers.

Braga, Paccagnella and Pellizari (2011), even, cite Krautmann and Sander (1999) to argue that, because students are more interested in obtaining the highest grade with the least possible effort, they generally "punish" with low values when a teacher makes them work more, which translate in a popularity assessment rather than an effectiveness one.

Moreover, since these assessments are often used to determine if a teacher is fired or remains in the institution, the result is that students end up taking classes with teachers who are not the best option.

Despite the foregoing, it is undeniable that assessing teachers' performance without recognizing the validity of students' opinions (those who are directly affected by that performance), produces an incomplete view of the teachers and their performance, and it limits the benefits of teachers' performance assessment.
Therefore, students' opinion should be taken into account, but it should not be the only indicator of teacher performance nor should it be used as a basis for the hiring / firing of teachers.

Moreover, opinion polls should not push students to make judgments about teachers as "poor" or "bad", but should sensitize students on the fact that they can help to identify skills or behaviors that could be considered positive and important for the proper development of the teaching-learning process in the institution.

Another aspect that raises controversy is the use of average values as a measure of teaching performance (Hornstein, 2017; Luskova \& Hudakova, 2013).

In this regard, it is true that the use of average values is exposed to biases caused, for example, by the way in which students respond to a questionnaire, and can even lead to interpretations such as that a teacher's performance is "bad" because it is "below average".

In these cases, the use of other statistical measures, such as mode or standard deviation, and even more complex indicators, might seem statistically more reliable. However, a teacher's level of effectiveness within the teachinglearning process relays not only on his/her level of knowledge of course topics, teaching tools and techniques, but also on his/her physical and mental state, the generational characteristics of students, and the socioeconomic environment at the time the assessment is performed (DarlingHammond, 2010).

Therefore, it may be more convenient to use an easy to calculate and understand value that provides an indication of the teacher's strengths and weaknesses without making judgements.

In addition to the above, the proposed model emphasizes the use of reflective practice, collaboration and participation, which can be a reason for discussion because it presupposes that actors are interested in the teaching-learning process improvement, and that this interest is expressed as a critical and purposeful attitude throughout the teachers' performance assessment process. Furthermore, the above has been discredited by studies where teachers themselves question their ability to perform a self-critical reflection on their teaching practice (Contreras, 2020). 
Also, many institutions have an organizational culture that either uses performance indicators as instruments of repression or derision, or has inadequate feedback on the assessment results, which creates distrust among the actors. In both cases, the result is a negative environment that leads to competition rather than collaboration among peers, and limits the teaching-learning process improvement (Benton \& Young, 2018; Jamshidian 2019).

To overcome such problems, it is essential to carry out a sensitization work prior to the start of the assessment process, where the emphasis on dialogue and understanding of the characteristics of collaborative work and its benefits, as well as transparency throughout the process, would be the framework that fosters actors' participation. Likewise, the individualized and confidential handling of the information would provide the teacher with greater freedom to plan and execute personal improvement strategies.

\section{Conclusions}

The main contribution of this project was the use of collaborative work of professors, students and managers as a base to assess teachers' performance in order to improve the teachinglearning process.

Another contribution of this project was the identification of factors that influence teachers' performance assessment, based on which it is possible that each school adapts the model according to its characteristics and the expected results.

Related to the proposed model, its strengths are (Cueva, 2020):

- The use of a tailored technological tool that makes the collection of students' opinion more flexible.

- $\quad$ The simple processing of information.

- The designing of general as well as individual improvement strategies.

- $\quad$ The fact that the teachers under assessment were in charge of the entire process, which not only provided a better environment for collaboration and joint reflection among them, but it also is not common in this type of practices.
It is worth mentioning that, although it is considered that good results have been obtained with the proposed model application so far, in order to improve the teaching-learning process it is necessary to incorporate students' selfassessment related to their academic performance, and teachers and students' assessment related to the effectiveness of the Monitoring Program.

In addition, it is necessary to improve the technological tool in such a way that the automation of the process is facilitated, without losing its flexible character.

\section{References}

Barker, B (2017). Creating a Collaborative Workplace: Amplifying Teamwork in Your Organization. Queen's University IRC, Ontario. Retrieved from https://irc.queensu.ca/sites/default/files/articles/ creating-a-collaborative-workplace-amplifyingteamwork-in-your-organization.pdf

Barrado, C., Gallego, I. \& Valero, M. (1999). Report UPC-DAC-1999-70: Usemos las encuestas a los alumnos para mejorar nuestra docencia. Universidad Politécnica de Cataluña. Retrieved from: http://docencia.ac.upc.edu/jododac/CD10anys/2 000/UPC-DAC-1999-70.pdf

Benton, S. \& Young, S. (2018). IDEA Paper 69: Best practices in the evaluation of teaching. Retrieved from https://www.ideaedu.org/Portals/0/Uploads/Doc uments/IDEA\%20Papers/IDEA\%20Papers/IDE A_Paper_69.pdf

Bertalanffy, L. (1989). Teoría general de los sistemas. Mexico: Fondo de Cultura Económica.

Braga, M., Paccagnella, M. \& Pellizzari, M. (2011). IZA Discussion Paper 5620: Evaluating students evaluation of professors. Retrieved from http://ftp.iza.org/dp5620.pdf

Bunge, N. (2018, November 27th). Students evaluating teachers doesn't just hurt teachers. It hurst students (Commentary). The Chronicle of Higher Education. Retrieved from https://www.chronicle.com/article/StudentsEvaluating-Teachers/245169 
Campbell, A. (2014). Understanding the teacher performance evaluation process from the perspective of Jamaican Public School teachers. (PhD Thesis) University of Toronto: Toronto, Canada. Retrieved from https://tspace.library.utoronto.ca/bitstream/1807 /68353/1/Campbell_Andrew_B_201406_PhD_t hesis.pdf

Cárdenas, M., Méndez. L. \& González, M. (2014). Evaluación del desempeño docente, estrés y burnout en profesores universitarios. Actualidades Investigativas en Educación, 14(1), pp.1-22. Retrieved from https://www.redalyc.org/articulo.oa?id=447298 76006

Casanova, J. (2017). Teacher Performance Evaluation: The Importance of Performance Standards. International Journal for CrossDisciplinary Subjects in Education (IJCDSE), 8(1), 2973-2981. Retrieved from https://infonomics-society.org/wpcontent/uploads/ijcdse/publishedpapers/volume-8-2017/Teacher-PerformanceEvaluation-The-Importance-of-PerformanceStandards.pdf

Checkland, P. (1999). Pensamiento de sistemas, práctica de sistemas. Mexico: Limusa.

Contreras, P. (2020). Reflexión crítica como elemento de profesionalización de la formación inicial del profesorado de historia. Revista Reflexión e Investigación Educacional, 2(2), 117-128. Retrieved from http://revistas.ubiobio.cl/index.php/REINED/art icle/view/4127/3824

Cueva, A. (2020). Trabajo colaborativo docente y su impacto en la gestión pedagógica. Ciencia y Educación, 1(1), 19-24. Retrieved from http://www.cienciayeducacion.com/index.php/j ournal/article/view/2/3

Darling-Hammond, L. (2010). Evaluating teacher effectiveness. How teacher performance assessments can measure and improve teaching. USA: Center for American Progress. Retrieved from

https://scale.stanford.edu/system/files/teacher_e ffectiveness.pdf

Del Rincón, D. \& Del Rincón, B. (2000). Revisión y mejora de procesos educativos. Revista Interuniversitaria de Formación del Profesorado, 39, 51-73. Retrieved from https://dialnet.unirioja.es/descarga/articulo/118 085.pdf
Domingo, A. (2013). Práctica reflexiva para docentes. Germany: Publicia. Retrieved from https://practicareflexiva.pro/wpcontent/uploads/2015/09/Practica-reflexivapara-docentes.pdf

Escalera, B.; Reíllo, A.; Torrado, G; \& Peña, M. (2012). Jornadas del ICE: Encuesta de opinión de los estudiantes sobre la calidad docente de las prácticas de Farmacia Clínica. Universidad de Alcalá. Retrieved from https://web.ua.es/es/ice/jornadas-redes2012/documentos/posters/244102.pdf

Gómez, V., García, M., Ramírez, J., Saldaña, S., García, L. \& Peña, A. (2008). Instrumento de evaluación de la práctica docente en medicina. Propuesta y validación. Rev Fac Med UNAM, 51(3), 99-103. Retrieved from https://www.medigraphic.com/pdfs/facmed/un2008/un083d.pdf

Hornstein, H. (2017). Student evaluations of teaching are an inadequate assessment tool for evaluating faculty performance. Cogent Education, $\quad 4, \quad 1304016 . \quad$ DOI: http://dx.doi.org/10.1080/2331186X.2017.1304 016

Jamshidian, S., Yamani, N., Sabri, M. \& Haghani, F. (2019). Problems and challenges in providing feedback to clinical teachers on their educational performance: A mixed-methods study. J Educ Health Promot, 8(8). DOI: 10.4103/jehp.jehp_189_18:10.4103/jehp.jehp_1 89_18

Krasner, G., \& Pope, S. (1988). A cookbook for using the model-view controller user interface paradigm in Smalltalk-80. The JOT (SIGS Publications). Also published as A Description of the Model-View-Controller User Interface Paradigm in the Smalltalk-80 System. ParcPlace Systems Report. Retrieved from https://web.archive.org/web/20100921030808/h ttp://www.itu.dk/courses/VOP/E2005/VOP200 5E/8_mvc_krasner_and_pope.pdf

Krautmann, A. \& Sander, W. (1999). Grades and student evaluations of teachers. Economics of Education Review, 18, 59-63. Retrieved from https://www.researchgate.net/publication/48359 96_Grades_and_Student_Evaluations_of_Teac hers

López, O., García, J., Batte, I.; \& Cobas, M. (2015). La mejora continua: objetivo determinante para alcanzar la excelencia en instituciones de educación superior. EDUMECENTRO, 7(4), 196-215. Retrieved from http://www.revedumecentro.sld.cu 
Loughran, J. (2002). Effective Reflective Practice: In Search of Meaning in Learning about Teaching. Journal of Teacher Education, 53(1), 33-43. DOI: $10.1177 / 0022487102053001004$

Luskova, M. \& Hudakova, M. (2013). Approaches to teacher's performance assessment for enhancing quality of education at universities. Procedia - Social and Behavioral Sciences, 106, 476-484. DOI: 10.1016/j.sbspro.2013.12.053

Mathew, P., Mathew, P. \& Peechattu, P. (2017). Reflective practices: a means to teacher development. Asia Pacific Journal of Contemporary Education and Communication Technology, 3(1), 126-131. Retrieved from https://apiar.org.au/wp-

content/uploads/2017/02/13_APJCECT_Feb_B RR798_EDU-126-131.pdf

OCDE (2011), Establecimiento de un marco para la evaluación e incentivos docentes: Consideraciones para México. OECD Publishing. DOI: http://dx.doi.org/10.1787/9789264059986-es. Retrieved https://www.oecd.org/education/school/ 48599568.pdf

Royce, W. (1970). Managing the Development of Large Software Systems: Concepts and Techniques. Mexico: Mc Graw Hill.

Schaak, L., \& Walker, J (2004). Talking teaching: implementing reflective practice in groups. Scarecrow Education, Maryland. Retrieved

from https://www.google.com/url?sa=t\&rct=j\&q=\&e src $=$ s\&source $=$ web $\& c d=\& v e d=2 a h U K E w i R 86$ PFuM3pAhUIbq0KHXkjB0EQFjALegQIBBA B\&url=http\%3A\%2F\%2Febooks.lib.unair.ac.id \%2Fdownload.php\%3Fid\%3D9730\&usg=AOv Vaw1eR_wT1VxXumbQuSKHY_RA

SEP (2011). Evaluación del desempeño docente. Cuestionario: versión final. México: Dirección General de Educación Superior Tecnológica. Retrieved from http://www.tepic.tecnm.mx/doc/Cuestionarioevaluacion-docente.pdf

Sondang, P., Perlindungan, L. \& Bonik, K. (2018). Teacher's behaviour towards students' motivation practice. SHS Web of Conferences 42 , 00078.

https://doi.org/10.1051/shsconf/20184200078
Sztejnberg, A., Brok, P. \& Jurek, J. (2004). Preferred teacher-student interpersonal behavior: differences between polish primary and higher education students' perceptions. Journal of Classroom Interaction, 39(2), 32-40. Retrieved from https://pdfs.semanticscholar.org/48fc/141c2b18 24166ba507c2701ca02b451515ed.pdf?_ga=2.7 5653270.282766402.15735966191827697748.1573596619

Thompson, C. (2016). Collaborative Work Environments: Development and Sustainability. Electronic Thesis and Dissertation form The University of Western Ontario. Retrieved from https://pdfs.semanticscholar.org/f579/47d57962 2fd95b58c5b88e5d91afbf7e99ad.pdf?_ga=2.12 3522184.288877309.15797286211981535076.1579728621

Universidad Iberoamericana (2010). Sistema de evaluación de procesos educativos. Mexico. Retrieved from https://ibero.mx/formaciondeprofesores/Evalua cion $\% 20$ docencia/wp $\% 20 \mathrm{AD}$ -

ED\%20SEPE\%201\%20Cuestionario.pdf

Universidad Veracruzana (2004). Evaluación al desempeño docente. Mexico. Retrieved from https://www.uv.mx/psicologia/files/2013/12/Ins trumento-de-evaluacion-desempeno-porConsejo-Tecnico.pdf

Valdés, H. (2004). Desempeño del maestro y su evaluación. La Habana: Pueblo y educación. Retrieved from https://www.yumpu.com/es/document/read/144 92298/desempeno-del-maestro-y-suevaluacion-hector-valdes-veloz

Valdés, H. (2009). Manual de buenas prácticas de evaluación del desempeño profesional de los docentes. Consejo Nacional de Educación de Perú. Retrieved from http://repositorio.minedu.gob.pe/handle/123456 $789 / 5039$

Van Gigch, J. 2a Ed. (2004). Teoría general de sistemas. México: Trillas. 